\title{
Effects of mineral content of bovine drinking water: Does iron content affect milk quality?
}

\author{
G. R. Mann, ${ }^{*}$ S. E. Duncan, ${ }^{* 1}$ K. F. Knowlton,† A. D. Dietrich, $\ddagger$ and S. F. O’Keefe* \\ *Department of Food Science and Technology, \\ †Department of Dairy Science, and \\ ‡Department of Civil and Environmental Engineering, Virginia Polytechnic Institute and State University, Blacksburg 24061
}

\begin{abstract}
The composition of water given to dairy cattle is often ignored, yet water is a very important nutrient and plays a major role in milk synthesis. The objective of this study was to study effects of elevated levels of iron in bovine drinking water on milk quality. Ferrous lactate treatments corresponding to $0,2,5$, and 12.5 $\mathrm{mg} / \mathrm{kg}$ drinking water concentrations were delivered through the abomasum at $10 \mathrm{~L} / \mathrm{d}$ to 4 lactating dairy cows over 4 periods ( $1 \mathrm{wk}$ infusion/period) in a Latin square design. On d 6 of infusion, milk was collected, processed (homogenized, pasteurized), and analyzed. Mineral content $(\mathrm{Fe}, \mathrm{Cu}, \mathrm{P}, \mathrm{Ca})$ was measured by inductively coupled plasma mass spectrometry. Oxidative stability of whole processed milk was measured by the thiobarbituric acid reactive substances (TBARS) assay for malondialdehyde (MDA) and sensory analysis (triangle test) within $72 \mathrm{~h}$ of processing and after $7 \mathrm{~d}$ of storage $\left(4^{\circ} \mathrm{C}\right)$. Significant sensory differences between processed milks from cows receiving iron and the control infusion were observed. No differences in TBARS $(1.46 \pm 0.04 \mathrm{mg}$ of $\mathrm{MDA} / \mathrm{kg})$ or mineral content $(0.22$ $\pm 0.01 \mathrm{mg} / \mathrm{kg} \mathrm{Fe}$ ) were observed. A 2-way interaction (iron treatment by cow) for $\mathrm{Ca}, \mathrm{Cu}$, and Fe concentrations was seen. While iron added directly to milk causes changes in oxidation of milk, high levels of iron given to cattle have subtle effects that initially may not be obvious.
\end{abstract}

Key words: milk, oxidation, metals, water

\section{INTRODUCTION}

Water is often overlooked as one of the most important nutrients for dairy cattle, yet cows consume a large amount, approximately $95 \mathrm{~L}$, of water per day (Chase, 2006). Global water demand for livestock is projected to reach $2.36 \times 10^{14} \mathrm{~L}$ in 2025 , an increase of over $630 \%$

Received May 30, 2013.

Accepted August 24, 2013.

${ }^{1}$ Corresponding author: duncans@vt.edu compared with the amount utilized in 1995. The dairy industry will be affected by the increased competition for water resources (Rosegrant and Cai, 2002).

Dairy farmers must be resourceful to overcome the challenges of water shortages. Recycling or reuse of water for dairy cattle consumption may become necessary to augment ground and surface water resources. Understanding possible implications of the mineral characteristics of water sources on cow health and milk quality is imperative (Collignon, 2009). Elevated levels of iron in the water given to cattle may affect milk synthesis and subsequent milk quality. Feng et al. (2013) identified that abomasal infusion of ferrous lactate, representing as much as $12.5 \mathrm{mg}$ of $\mathrm{Fe} / \mathrm{L}$ in bovine drinking water, decreased digestibility of DM, NDF, and N, although $\mathrm{P}$ absorption was not affected. Although Feng et al. (2013) did not observe any effects on milk yield or gross milk composition, an excess of any heavy metal, particularly the pro-oxidants $\mathrm{Fe}$ and $\mathrm{Cu}$, may cause adverse effects on milk quality (Hegenauer et al., 1979a).

Iron in raw milk is naturally found at levels of approximately $0.5 \mathrm{mg} / \mathrm{kg}$ with a range of 0.3 to $0.6 \mathrm{mg} / \mathrm{kg}$ (Hunt and Nielsen, 2009). Milk exposed to pro-oxidant minerals, specifically $\mathrm{Cu}^{2+}, \mathrm{Fe}^{2+}$, and $\mathrm{Mn}^{2+}$, quickly oxidizes through the auto-oxidation cascade (initiation, propagation) of unsaturated fatty acids in the neutral fat or phospholipids (Hegenauer et al., 1979a,b; Chaplin, 1984; Gaucheron et al., 1996; Gaucheron, 2000; Raouche et al., 2009). An imbalance of pro-oxidant metals and antioxidants in the system can contribute to the propagation of the reaction, degradation of the lipid substrates, and production of short-chain, volatile aldehydes and ketones. Many of the volatile end-products, even at low concentrations, contribute to odors, flavors, and aromas and quickly override the bland, slightly sweet taste of high-quality milk. Metallic perception, characterized as the sensations typical of metal foil or a penny placed in the mouth, is associated with early stages of metal-induced oxidation in milk, whereas a highly oxidized sample is detectable by smell and a puckery mouthfeel (Alvarez, 2009). At concentrations above the sensory threshold, the combined impression 
of these volatiles in milk is characterized as "papery, cardboardy, metallic, painty, fishy" (Alvarez, 2009). Off-flavor effect may occur not only in milk but also in foods using oxidized dairy ingredients, and can be readily perceived by consumers when compared with the flavor of untainted products (White and Bulthaus, 1982). The ramifications of these off-flavors can decrease consumer satisfaction and contribute to declining product sales.

The incidence of metal-induced oxidation in milk is generally low; sporadic episodes may be attributed, in addition to contact with raw metals (as mentioned above), to high concentrations of trace metals in feed sources or divalent cations in water supplies used for cleaning and sanitizing milk-contact equipment (Alvarez, 2009). The relationship of these metals in bovine drinking water to the synthesis of milk and subsequent milk quality is not well understood.

High concentrations of iron and other heavy metals in drinking water may arise from natural levels in ground water, run-off from mining or other contaminating sources, drought conditions, or even from the watering systems used for storing water for animal consumption (McNeill, 2006; Bury et al., 2011). Iron concentrations in groundwater sources are variable. In a study of mineral composition of well water across the United States, iron concentration in southwestern Virginia ranged from $<10$ to $>300 \mu \mathrm{g} / \mathrm{kg}$ (Ayotte et al., 2011). Mann et al. (2013) reported iron content of bovine drinking water sources on 13 dairy farms in Virginia; 6 farms did not have any detectable iron concentrations, and one farm had high iron concentrations $(0.46 \mathrm{mg} / \mathrm{L})$ above the US Environmental Protection Agency (USEPA) secondary maximum contaminant level (SMCL) of $0.3 \mathrm{mg} / \mathrm{kg}(300 \mu \mathrm{g} / \mathrm{kg})$. Iron concentration in drinking water above the USEPA SMCL can affect copper and zinc absorption and, thus, may affect cattle health and performance (Murthy et al., 1972; USEPA, 2011). However, little research has been identified that examines the specific role of iron in the water given to dairy cattle (Sugiarto et al., 2010). It is known that iron can affect palatability of the water provided to cattle, which may cause the animals to consume less water, leading to less milk production (USEPA, 2011).

Our goal was to determine if excess iron, as in water provided to cattle, altered processed milk composition and affected processed milk properties, specifically oxidative stability. The objectives of this study were to characterize the effect of low, moderate, and high levels of iron, through (1) direct addition into processed milk, and (2) indirect addition (abomasal infusion) via bovine milk synthesis, on mineral composition and oxidative stability (sensory, analytical analyses) of processed fluid milk.

\section{MATERIALS AND METHODS}

\section{Effect of Direct Addition of Iron on Oxidative Stability of Milk}

Product Preparation. Milk [3.25\% milkfat, pasteurized (HTST), homogenized vitamin D] was purchased from the local supermarket in five 3.79-L (1 gallon) packages (high-density polyethylene, no visible light protection additives). All packages, having the same code date with at least $7 \mathrm{~d}$ remaining on the date of purchase, were selected from the front-row display on neighboring levels. Products were purchased on 3 different occasions for replication, with each purchase date representing a unique code date. Each gallon of milk was prepared such that approximately $3 \mathrm{~L}$ remained in the original packaging by means of removing and discarding $785 \mathrm{~mL}$ of the commercial milk.

Four iron stock solutions (control: $0 \mathrm{mg} / \mathrm{kg}$, low: 0.3 $\mathrm{mg} / \mathrm{kg}$, medium: $3 \mathrm{mg} / \mathrm{kg}$, high: $30 \mathrm{mg} / \mathrm{kg}$ ) were made with food-grade ferrous sulfate $\left(\mathrm{FeSO}_{4}\right.$, CAS 1346343-g; Sigma-Aldrich, St. Louis, MO). Stock solutions were prepared by adding ferrous sulfate (control: no addition; low: $0.010 \mathrm{~g}$; medium: $0.10 \mathrm{~g}$; high: $1.0 \mathrm{~g}$ ) into distilled water $(30 \mathrm{~mL}$; wt/wt) with agitation. A $30-\mathrm{mL}$ aliquot of each stock solution was added into milk within $1 \mathrm{~h}$ of stock preparation and within $24 \mathrm{~h}$ of purchase (1 package per iron concentration; 2 packages per control). Calculated ferrous sulfate concentrations added to the milk, based on stock solution addition, were $0 \mathrm{mg} / \mathrm{kg}$ added (control), $0.0027 \mathrm{mg} / \mathrm{kg}$ added (low), $0.027 \mathrm{mg} / \mathrm{kg}$ added (medium), and $0.27 \mathrm{mg} / \mathrm{kg}$ added (high); the highest level of addition providing a 50 to $90 \%$ increase compared with the reported concentrations in milk $(0.3-0.6 \mathrm{mg} / \mathrm{kg}$; Hunt and Nielsen, 2009). Milk was stored in a dark, walk-in cooler at $4^{\circ} \mathrm{C}$ for $3 \mathrm{~d}$ before analyses were completed. Oxidative stability was determined by sensory triangle test analyses and thiobarbituric acid reactive substances (TBARS) assay.

Analytical Assessment of Oxidation. The TBARS analyses were completed to measure secondary metabolites of oxidation (aldehydes), specifically malondialdehyde (MDA), which can indicate oxidation (Spanier and Traylor, 1991). Each sample (1 mL) was homogenized in a $15-\mathrm{mL}$ plastic centrifuge tube by means of a vortex before the analysis and weighed for accuracy. Samples were diluted by adding $4 \mathrm{~mL}$ of distilled water and recovering $1 \mathrm{~mL}$ of the diluted sample for analysis. Then, $2 \mathrm{~mL}$ of solution I $(0.375 \%$ thiobarbituric acid, $0.506 \%$ SDS, $9.370 \%$ acetic acid) was added with $0.1 \mathrm{~mL}$ of solution III (antioxidant and chelator solution). Samples were vortexed to ensure proper mixing. Samples were capped and kept at $95^{\circ} \mathrm{C}$ 
in a water bath for $60 \mathrm{~min}$. Cooled samples were placed under a fume hood, and $2.5 \mathrm{~mL}$ of solution II (15:1 mixture of $n$-butanol and pyridine) were added. Samples were mixed by vortexing for $10 \mathrm{~s}$ each and then centrifuged at $25^{\circ} \mathrm{C}$ at $1,600 \times g$ for $15 \mathrm{~min}$. Approximately 2.5 to $3 \mathrm{~mL}$ of the top-layer organic solution was pipetted into a cuvette and the absorbance was read at 532 $\mathrm{nm}$ (Milton Roy Spectronic 21D Spectrophotometer, Milton Roy Company, Rochester, NY) under a fume hood. The amount of MDA per sample was determined by using a standard curve made by means of a linear regression on absorbance values and concentration $(\mathrm{mg} / \mathrm{kg})$ of malondialdehyde of the 4 standard tetramethoxypropane (TMP) solutions. Standard solutions, one per concentration, were $0,2.5,5$, and $7 \mu \mathrm{mol}$ of TMP.

Sensory Assessment. The Virginia Tech Institutional Review Board approved the use of human subjects for the sensory testing in this study (IRB 12-158). Triangle tests for differences were used to determine if samples were perceptibly different, possibly as a function of oxidation. Sensory testing occurred in the sensory laboratory of the Food Science and Technology Department. Participants were recruited from faculty, staff, and students at Virginia Tech. Panelists were seated in individual booths under white lighting. Testing was managed using the Sensory Information Management System (SIMS) software (Sensory Computer System LLC, Morristown, NJ). Data were collected using touchscreen monitors and downloaded to the server, and data compilation for each triangle test was completed by the software.

Experimental Design and Statistical Evaluation. Duplicate TBARS assays for each sample were completed in each replicate $(\mathrm{n}=3)$. An ANOVA was performed to determine differences between treatments. Sensory testing was completed only on the first replication. Statistical parameters for sensory testing by triangle tests were $\alpha=0.05, \beta=0.20$, and proportion of discriminators $\left(\mathbf{p}_{\mathbf{d}}\right)$ of $30 \%$, requiring 43 sensory participants (43 observations per test comparison). A critical number of 21 correct observations per test comparison was needed to claim that the 2 samples were different (Meilgaard et al., 2007).

\section{Influence of Abomasal Infusion of Iron on Oxidative Stability of Processed Milk}

Preharvest Management. Milk from this study of the indirect effect of iron in bovine drinking water on processed milk quality was collected from cows receiving abomasal infusion as previously described (Feng et al., 2013). Institutional Animal Care and Use Committee (IACUC) approval was obtained (12-027-DASC).
During the treatment period, 4 ruminally cannulated, early lactation (second lactation) cows (2 Holstein and 2 Holstein $\times$ Jersey cross) were isolated from external water sources, housed in individual stalls, and given a standard basal diet offered at 5 to $10 \%$ (wet basis) in excess of the previous day's intake and a standardized water source. Iron content of the diet was standardized at $651 \mathrm{mg} / \mathrm{kg}$.

Ferrous lactate $\left(\mathrm{C}_{6} \mathrm{H}_{10} \mathrm{FeO}_{6}\right)$ treatments were prepared at 4 concentrations: control $(0 \mathrm{mg} / \mathrm{kg})$, low $(200$ $\mathrm{mg} / \mathrm{kg})$, medium $(500 \mathrm{mg} / \mathrm{kg})$, and high $(1,250 \mathrm{mg} /$ $\mathrm{kg}$ ) using double-distilled water, and the iron content of each solution was monitored each day (Feng et al., 2013). These levels corresponded to drinking water levels of $0,2,5$, and $12.5 \mathrm{mg} / \mathrm{kg}$, assuming each cow drinks $100 \mathrm{~L} / \mathrm{d}$; the 2 highest levels exceeded the USEPA SMCL limits and represented approximate 0.8 and $2 \%$ increases over dietary iron, respectively. Cows were infused with $1 \mathrm{~L} / \mathrm{d}$ via the abomasum. Each cow received all iron water treatments in a $4 \times 4$ Latin square design, randomly assigned order, during each of four 2-wk periods (Table 1). Each period began with a 7-d washout period when the cattle were individually fed once per day in Calan doors (American Calan, Northwood, NH), with consistent access to feed and water except during milking, and received no abomasal infusion. From d 8 to 14, each cow was fed twice daily (0600 and $1800 \mathrm{~h}$ ) in individual stalls and received assigned treatments as previously described.

Milk Collection. Milk was discarded from d 8 through d 13 of the 2 -wk period. On d 13 of each period (d 6 infusion), milk from the evening (1800 h) milking of each cow was collected. Raw milk was collected in 18.9-L (5-gallon) stainless steel milk cans, transported immediately to the Food Science and Technology Dairy Processing Laboratory, and stored at $4^{\circ} \mathrm{C}$ in a large walk-in cooler. Milk from each cow was processed within $18 \mathrm{~h}$ of collection. For a more detailed outline of the design, see Table 2.

Milk Processing, Packaging, and Storage. Milk from each cow was processed separately. Milk was separated and standardized to achieve $3.18 \% \pm 0.04 \%$ milkfat, as verified by the Babcock procedure using AOAC method 989.04 (AOAC International, 2000). Milk was homogenized using a laboratory 2-stage homogenizer [first stage: $13.8 \mathrm{MPa}(2,000 \mathrm{psi})$; second stage: 5.52 MPa (800 psi); model 15MR, 55.2 MPa (8000psi), APV Gaulin Inc., Everett, MA). Standardized, homogenized milk was vat pasteurized at $66^{\circ} \mathrm{C}$ for $30 \mathrm{~min}$ and effectiveness of the pasteurization was verified microbiologically with SPC following standard methods (Laird et al., 2004). Cooled processed milk, 7.57 L per cow (treatment), was packaged in sanitized, translucent (no light protective additives), food-grade high-density 
Table 1. The $4 \times 4$ Latin square design illustrating randomization (between cows; within cow) assignments of iron concentration ${ }^{1}$ for abomasal infusion for each period ${ }^{2}$

\begin{tabular}{|c|c|c|c|c|}
\hline Cow no. ${ }^{3}$ & Period 1 & Period 2 & Period 3 & Period 4 \\
\hline 4541 & Control & Low & Medium & High \\
\hline 4543 & Low & High & Control & Medium \\
\hline 4558 & Medium & Control & High & Low \\
\hline 4559 & High & Medium & Low & Control \\
\hline
\end{tabular}

${ }^{1}$ Each 10-L solution contained control $(0 \mathrm{mg} / \mathrm{kg})$, low $(200 \mathrm{mg} / \mathrm{kg})$, medium $(500 \mathrm{mg} / \mathrm{kg})$, or high $(1,250 \mathrm{mg} /$ $\mathrm{kg}$ ) levels of ferrous lactate.

${ }^{2}$ Period of infusion: 7-d post-washout period; each cow was infused with $1 \mathrm{~L} / \mathrm{d}$ of the assigned iron treatment.

${ }^{3}$ Jersey $\times$ Holstein $(4541,4543)$ and Holstein $(4558,4559)$.

polyethylene gallon packages. Packages were stored at $4^{\circ} \mathrm{C}$ with no light exposure for $11 \mathrm{~d}$.

Milk Analyses. All analyses were completed within $72 \mathrm{~h}(3 \mathrm{~d})$ of processing in the first week and repeated 1 wk later following the same sequence (day) of analyses. Each period sequence was as follows: processing (d 0), TBARS (d 1, d 8), GC-MS and sensory (d 2, d 9), protein, ash, and inductively coupled plasma (ICP)MS preparation (d 3, d 10). For reporting in this paper, analyses completed within $72 \mathrm{~h}$ of milk processing are designated $\mathrm{d} 1$, and wk 2 analyses, which were completed within the same 7 -d time interval, are designated d 8.

Gross Composition. Milk was analyzed for gross composition (total protein, ash, lipid based on Babcock method as previously described) and mineral composition. Protein content was determined following the instructions using a commercial protein analysis kit (2-D Quant Kit, General Electric, Fairfield, CT). Percentage ash was measured using the gravimetric method (AOAC International, 2000; method 945.46).

Mineral Analyses and Analytical Assessment of Oxidation. Calcium, copper, iron, and inorganic phosphorus concentrations were measured by ICP-MS (X-Series ICP-MS, Thermo Electron Corp., Waltham, MA) using Standard Method 3125B (Rice et al., 2012). Before ICP-MS, the milk was prepared using a modified nitric acid digestion procedure based on a method described for infant formula (Suddendorf and Cook, 1984).

Oxidative stability of milk was estimated based on assessment of MDA by TBARS as previously described. Duplicate TBARS assays were completed each week, 2 per period for 4 periods.

Sensory Evaluation. Sensory evaluation was used to determine if overall differences in flavor and odor existed between milk from control and iron-infused cows for each treatment level. Virginia Tech Institutional Review Board approval was received before recruitment of human subject participants (IRB 12-227). Participants were recruited from faculty, staff, and students at Virginia Tech.
Milk samples $(\sim 30 \mathrm{~mL})$ were poured into portion cups $(60 \mathrm{~mL})$, capped with lids, and refrigerated $\left(4^{\circ} \mathrm{C}\right)$ until testing. Samples were coded with 3 -digit numbers. Triangle test samples (control versus iron treatment) were presented in a balanced order as determined by the SIMS software (Sensory Computer System LLC). Sensory testing conditions were the same as described in the direct iron addition study.

Panelists were asked to taste each sample, comparing the milk aroma and flavor, and identify which sample was different from the other two. Participants completed 3 sensory triangle tests on both $\mathrm{d} 1$ and $\mathrm{d}$ 8 , comparing milk from the control cow to each treatment. The order of the 3 triangle tests and within each 3 -sample test was balanced across panelists.

Experimental Design and Statistical Evaluation. A Latin square design was used for assigning iron-infusion treatments to each cow $(\mathrm{n}=4$ replications). Virginia Tech's Laboratory for Interdisciplinary

Table 2. The study consisted of 4 periods where each cow received 1 of 4 treatments ${ }^{1}$ for one period as shown and milk was picked up to be processed on d 13

\begin{tabular}{lcl}
\hline $\begin{array}{l}\text { Day of } \\
\text { the week }\end{array}$ & $\begin{array}{c}\text { Period } \\
\text { day }\end{array}$ & Treatment ${ }^{2}$ \\
\hline Tuesday & 1 & Washout \\
Wednesday & 2 & Washout \\
Thursday & 3 & Washout \\
Friday & 4 & Washout \\
Saturday & 5 & Washout \\
Sunday & 6 & Washout \\
Monday & 7 & Washout \\
Tuesday & 8 & Infusion \\
Wednesday & 9 & Infusion \\
Thursday & 10 & Infusion \\
Friday & 11 & Infusion \\
Saturday & 12 & Infusion \\
Sunday & 13 & Infusion \\
Monday & 14 & Infusion
\end{tabular}

${ }^{1}$ Control $(0 \mathrm{mg} / \mathrm{kg})$, low $(200 \mathrm{mg} / \mathrm{kg})$, medium $(500 \mathrm{mg} / \mathrm{kg})$, and high $(1,250 \mathrm{mg} / \mathrm{kg})$ ferrous lactate. Ferrous lactate solutions were made using ultrapure water and were provided for four days before milk collection.

${ }^{2}$ Washout period $=$ no abomasal infusion; infusion period $=$ abomasal infusion of ferrous lactate solution. 
Statistical Analysis (LISA) was consulted to ensure appropriate statistical analyses were used. A randomeffects ANOVA was used to determine the effects of infused iron on the dependent variable of composition (total protein, ash, concentration of each mineral) using JMP Pro Statistical Discovery Software (version 10.0.0; SAS Institute Inc., Cary, NC). Effects of time (2 levels: $\mathrm{d} 1, \mathrm{~d} 8$ ) and treatment (4 levels of iron) on oxidative stability parameters (TBARS, total volatiles) were analyzed by Tukey-Kramer analysis. If no time effects were observed, values were treated as duplicates to increase the power of the test. A cross effects analysis was completed to see the effects of 2-way and 3-way interactions $($ cow $\times$ treatment, treatment $\times$ period, period $\times$ cow, and cow $\times$ period $\times$ treatment) for gross composition dependent variables (protein, ash) and TBARS. An effects test of week nested within treatment was also run for TBARS. Mean values and standard errors for each dependent variable were calculated for each iron-infusion treatment by week (day). All statistical measures were carried out with a predetermined $\alpha$ of 0.05 .

Statistical parameters for sensory testing were preset at $\alpha=0.05, \beta=0.3$, and $\mathrm{p}_{\mathrm{d}}$ of $30 \%$, and required a minimum of 36 observations per comparison on each day of testing (Meilgaard et al., 2007). A critical number of 18 correct observations per test comparison was needed to determine that the treatment milk was different from the control milk on each testing day of each period ( $\mathrm{n}=36$ participants; Meilgaard et al., 2007). A critical number of 58 correct observations per overall test comparison over the 4 periods $(\mathrm{n}=144$ total observations) was needed to establish that a significant difference existed between control and treatments for $\mathrm{d}$ 1 and for $\mathrm{d} 8$. The combined $(\mathrm{d} 1+\mathrm{d} 8)$ observations (n $=288$ ) per comparison required a critical number of 96 to establish if a significant difference existed between control and each treatment.

\section{RESULTS AND DISCUSSION}

\section{Effect of Direct Addition of Iron on Oxidative Stability of Milk}

The addition of water to raw or processed fluid milk is not legal (FDA, 2011), although potable water may be added as an ingredient in reconstituted fluid products or in dairy products. Incidental water addition occurs indirectly, in very small volumes, through drops of rinse water from equipment or packaging. Such minor amounts of water, when contaminated with iron or copper, may be sufficient to contribute to oxidation of milk and degradation of milk quality. It is possible that iron remains in the form of salts such as ferrous chloride on the processing equipment and then contaminates milk processed on the machinery.

In this study, MDA was low $(0.28 \pm 0.00 \mathrm{mg}$ of $\mathrm{MDA} / \mathrm{kg}$ of milk) in the control sample (no iron addition), whereas MDA in milk with the high iron addition reached $1.68 \pm 0.07 \mathrm{mg} / \mathrm{kg}$ (Figure 1). An MDA of 1.3 $\mathrm{mg} / \mathrm{kg}$ milk (2\% fat) may be sufficient to distinguish light-oxidized milk from nonoxidized milk, based on sensory discrimination (triangle) tests (Johnson et al., 2013). van Aardt et al. (2005) reported similar MDA values in light-protected processed milk with antioxidants (tocopherol and ascorbic acid) added, suggesting that the milk used in the current study had very low aldehyde concentrations. We found no significant differences $(P>0.05)$ in MDA concentrations between the control milk and milk contaminated with low levels of iron $\left(0.3 \mathrm{mg}\right.$ of $\mathrm{FeSO}_{4} / \mathrm{kg}$ of water; the USEPA SMCL for iron in water) added to the milk $(0.0028 \mathrm{mg}$ of additional $\mathrm{FeSO}_{4} / \mathrm{kg}$ of milk; Figure 1). However, water containing $3 \mathrm{mg}$ of $\mathrm{FeSO}_{4} / \mathrm{kg}$ did increase the MDA concentrations significantly $(P<0.05)$ in milk $(0.028$ mg of additional $\mathrm{FeSO}_{4} / \mathrm{kg}$ of milk) compared with the control and low $\left(0.0028 \mathrm{mg}\right.$ of additional $\mathrm{FeSO}_{4} / \mathrm{kg}$ of milk) iron-containing water treatments (Figure 1). Concentrations of MDA in the low iron treatment were within the reported range of MDA concentrations in light-protected milk (van Aardt et al., 2005). van Aardt et al. (2005) also reported an MDA concentration of $0.92( \pm 0.09) \mathrm{mg} / \mathrm{kg}$ in milk exposed to light under refrigerated conditions for $10 \mathrm{~h}$, which is lower than the MDA concentrations observed in the medium and high iron-addition treatments in this study. The concentration of MDA in milk with the high iron treatment was significantly higher than that of milk with the medium treatment and above the TBARS value of 1.3 suggested as a sensory threshold for perceptible oxidation (Johnson et al., 2013). The TBARS assay, reported as MDA concentration, provides an indication of total aldehydes, which are secondary oxidative products from oxidation reactions and important contributors to both light-induced and auto-oxidation off-flavors (Alvarez, 2009). A low concentration of aldehydes is natural in both goat and cow milks $(0.3-0.5 \mathrm{mg}$ of $\mathrm{MDA} / \mathrm{kg}$; van Aardt et al., 2005; Matak et al., 2007) but when oxidation occurs, aldehyde concentrations increase and can markedly alter milk flavor and aroma (van Aardt et al., 2005). Although analytical measures of oxidation, including TBARS, conjugated dienes, peroxide values, and volatile chemistry, are often used as an indication of auto-oxidation and light-induced oxidation in milk, these methods are not as sensitive as human sensory methods (van Aardt et al., 2005; Alvarez, 2009; Moore et al., 2012). Sensory perception is often used because 


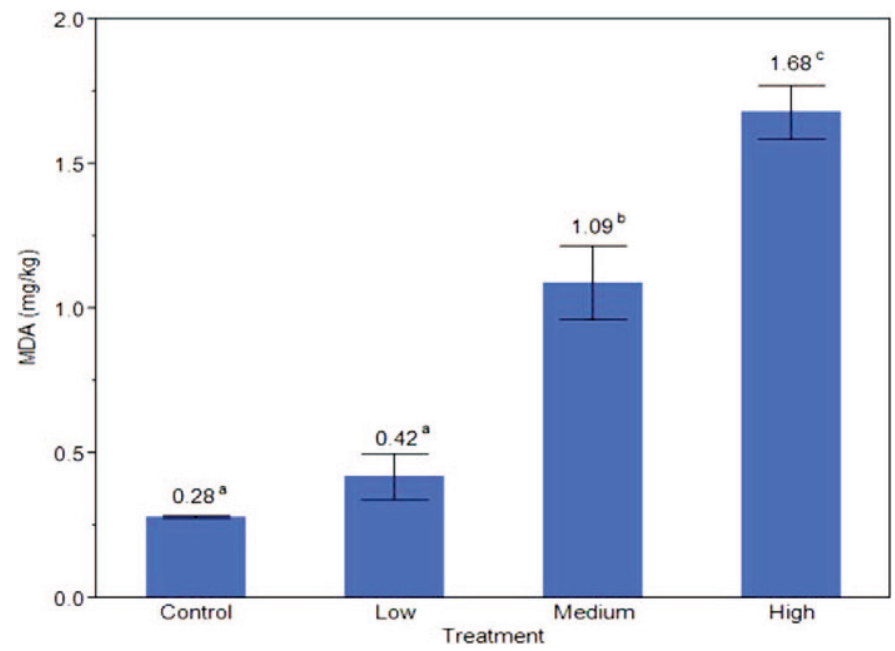

Figure 1. Malondialdehyde (MDA) concentrations (mg/kg; mean $\pm \mathrm{SE} ; \mathrm{n}=3$ ) as an indication of oxidation in commercially processed milk directly treated with iron (added as ferrous sulfate) solutions at 4 levels: control $(0 \mathrm{mg} / \mathrm{kg}$; low $(0.3 \mathrm{mg} / \mathrm{kg})$; US Environmental Protection Agency secondary maximum contaminant level); medium (3 $\mathrm{mg} / \mathrm{kg})$; and high $(30 \mathrm{mg} / \mathrm{kg})$. Final (added) iron concentrations in milk were control $(0 \mathrm{mg} / \mathrm{kg})$; low $(0.0028 \mathrm{mg} / \mathrm{kg})$; medium $(0.028$ $\mathrm{mg} / \mathrm{kg})$; and high $(0.28 \mathrm{mg} / \mathrm{kg})$. Milk was stored for $3 \mathrm{~d}\left(4^{\circ} \mathrm{C}\right.$; no light exposure). Iron concentration in milk typically ranges from 0.3 to 0.6 $\mathrm{mg} / \mathrm{kg}$. Error bars display standard error of the mean. Statistically significant differences $(P<0.05)$ are represented by different letters, determined by ANOVA. Color version available in the online PDF.

it is more sensitive than analytical methods (Ogden, 1993).

Sensory results confirmed that the addition of iron contributed to sensory differences, even at the low level of iron addition (USEPA SMCL concentration). Panelists $(\mathrm{n}=43)$ detected sensory differences compared with the control at low (22 correct observations; $P<$ 0.01), medium (25 correct observations; $P<0.001$ ), and high (32 correct observations; $P<0.001$ ) iron addition levels, which suggests that the sensory difference between a nonoxidized and a slightly oxidized milk sample may be more sensitive than the TBARS assay and that the incidental contamination of milk with water containing iron can affect milk sensory quality (Table 5). Although not specifically tested, the justnoticeable sensory difference between a nonoxidized sample and a slightly oxidized sample (control vs. low iron sample) may correspond to as little as $0.2 \mathrm{mg}$ of MDA/kg, based on the TBARS assay. This estimate is based on a direct sensory comparison of samples using a triangle test method and may not be sufficient to identify oxidation in an independent sample by an untrained consumer. These subtle differences did not seem to have the same effect in the subsequent study, perhaps because of the source of milk (individual cows rather than commingled source) and processing (vat rather than HTST pasteurization).
It is well known that the addition of iron to milk by direct addition (Gaucheron et al., 1996; Gaucheron, 2000; McKie et al., 2001; Raouche et al., 2009) and to various milk products (unstandardized, skim milk, infant formula) causes oxidation (Hegenauer et al., 1979a; Gaucheron et al., 1996; Satué-Gracia et al., 2000; Raouche et al., 2009). Iron is quite unstable, particularly in the ferrous form (McKie et al., 2001), and rapidly initiates auto-oxidation of unsaturated fatty acids. However, this study documented that even a small amount of iron, such as might be found in the water source used within the dairy farm or processing plant for cleaning of cows, equipment, or packaging, can affect quality of the final product.

\section{Influence of Abomasal Infusion of Iron on Oxidative Stability of Processed Milk}

Compositional analyses of the raw milk used in this study were reported in Feng et al. (2013). Protein $(3.8 \%)$, fat $(3.2 \%)$ and ash $(0.6 \%)$ content of the processed milk were not different $(P>0.05)$ with respect to cow, week, or treatment, and were within normal ranges for processed milk (Murthy et al., 1972; Jenness, 1974; Goff and Hill, 1993; Moreno-Rojas et al., 1993, 1994). However, processing period did have a significant effect on percentage protein (data not shown) and we observed a statistically significant $(P=0.01) 3$-way interaction (treatment $\times$ cow $\times$ period). Differences in composition may be attributed to small variations in processing conditions, differences in cow breed, stage of lactation, and progression of the season (Jensen, 1995).

Iron, $\mathrm{Cu}, \mathrm{P}$, and $\mathrm{Ca}$ concentrations in the processed milk did not differ significantly $(P>0.05)$ among the different Fe infusion treatments $(935 \pm 26 \mathrm{mg} / \mathrm{kg} \mathrm{Ca}$, $0.040 \pm 0.001 \mathrm{mg} / \mathrm{kg} \mathrm{Cu}, 0.220 \pm 0.010 \mathrm{mg} / \mathrm{kg} \mathrm{Fe}$, $847 \pm 27 \mathrm{mg} / \mathrm{kg}$ P) based on ANOVA. Main effects tests did show significant interactions for $\mathrm{Ca}, \mathrm{Cu}$, and $\mathrm{Fe}$ for 2 -way interaction of cow $\times$ treatment $(P$ $<0.05$ ), suggesting that treatment may have affected mineral composition of milk differently among cows. Previous studies on commercially processed milk have shown that mineral content varies, perhaps based on analytical procedure as well as milk source (Murthy et al., 1972; Hunt and Meacham, 2001; Birghila et al., 2008; Hunt and Nielsen, 2009).

Mineral concentrations in processed milk range between 1,097 and $1,495 \mathrm{mg} / \mathrm{kg} \mathrm{Ca}, 0.042$ and $0.18 \mathrm{mg} /$ $\mathrm{kg} \mathrm{Cu}, 0.17$ and $1.45 \mathrm{mg} / \mathrm{kg} \mathrm{Fe}$, and 854 and $930 \mathrm{mg} / \mathrm{kg}$ P (Murthy et al., 1972; Goff and Hill, 1993; Rodríguez Rodríguez et al., 1999; Hunt and Meacham, 2001; Hunt and Nielsen, 2009). Based on preliminary spike-recovery trials, the percentage recovery from extraction and ICP-MS analysis is approximately $52 \% \pm 5 \%$ for the 
selected methodology. Published concentrations of Ca, $\mathrm{Cu}, \mathrm{Fe}$, and inorganic $\mathrm{P}$ in processed whole milk, based on US Department of Agriculture's Nutrient Database (USDA, 2013), are $1,130 \mathrm{mg} / \mathrm{kg}, 0.11 \mathrm{mg} / \mathrm{kg}, 0.30 \mathrm{mg} /$ $\mathrm{kg}$, and $910 \mathrm{mg} / \mathrm{kg}$, respectively. Concentrations for $\mathrm{Ca}, \mathrm{Cu}, \mathrm{Fe}$, and $\mathrm{P}$ were $82,36,74$, and $93 \%$ of the US Department of Agriculture's reported values for whole (3.25\%) milk (USDA, 2013).

Atomic absorption spectroscopy of mineral composition in commercially processed milk showed broad ranges in $\mathrm{Cu}(0.042-0.18 \mathrm{mg} / \mathrm{kg} \mathrm{Cu})$ and Fe concentrations (0.20-1.45 mg/kg Fe; Murthy et al., 1972). Birghila et al. (2008) reported Fe concentrations in pasteurized milk from $0.8 \mathrm{mg} / \mathrm{kg}$ to as high as 11.84 $\mathrm{mg} / \mathrm{kg}$, displaying that iron levels in milk vary widely. It is known that $\mathrm{Cu}$ precipitates easily at a moderate $\mathrm{pH}(\sim \mathrm{pH} 6)$ and that Fe has a tendency to lower pH (Chaplin, 1984; Gaucheron et al., 1996; Balintova and Petrilakova, 2011). Method of analysis does seem to have an effect on mineral recovery, contributing to a wide range in reporting of mineral concentrations. Studies on mineral waters have shown lower recovery rates for $\mathrm{Fe}$ and $\mathrm{Cu}$ compared with those for $\mathrm{Al}, \mathrm{Ni}$, or Mo (Haraguchi et al., 2004).

The minerals reported in this study were selected for their role as pro-oxidants $(\mathrm{Cu}, \mathrm{Fe})$ or for their importance in casein stability and dairy product processing (Ca, P). Colloidal $\mathrm{Ca}$ and $\mathrm{P}$ are strongly associated with the casein proteins of milk (Goff and Hill, 1993). The Ca:P ratio $(\sim 4: 3)$ is important to note because it plays a vital role in cheese making and balancing the $\mathrm{pH}$ for proper ripening (Upreti and Metzger, 2007). Cheese curd, mostly casein, contains calcium phosphate $\left[\mathrm{Ca}_{3}\left(\mathrm{PO}_{4}\right)_{2}\right]$. Cheese-making potential for milk can be influenced by the Ca:P ratio because calcium phosphate plays an integral part is curd formation and stabilization (Cerbulis and Farrell, 1976; Hutkins, 2006). Significant interactions for the 3 -way interaction between treatment $\times$ cow $\times$ period were observed for both $\mathrm{Cu}$ and $\mathrm{Fe}$ in this study. The $\mathrm{Ca}: \mathrm{P}$ ratio (based on overall means) in this study was about $3.3: 3$, which is slightly lower than the normal (literature-based) ratio. However, the wide variation for each mineral in the study suggests that the calculated ratio of 3.3:3 may not apply to each cow.

Copper levels in milk are attributed to $\mathrm{Cu}$ concentrations in feed (Havemose et al., 2006) but very little information exists about the relationship of Fe concentrations in feed or water associated with changes in $\mathrm{Fe}$ concentrations in the milk (Underwood, 1971; Murthy et al., 1972). Copper and Fe content in milk are affected by lactation stage; Fe content is also dependent on breed, season of the year, and other cow-handling methods (Moreno-Rojas et al., 1993; Sikiric et al., 2003).
Postmilking $\mathrm{Fe}$ and $\mathrm{Cu}$ contamination was historically associated with cans, pipes, or other storage methods (Underwood, 1971; Murthy et al., 1972). However, this is less common now as the dairy industry has shifted the use of $\mathrm{Cu}$ and galvanized pipes to stainless steel and other materials (Clark et al., 2009; Anonymous, 2010).

The experimental study showed more variation in mineral composition than in the preliminary spikerecovery study discussed earlier. The direct Fe addition study was based on 5 replicate analyses from 2 different commercially processed samples and illustrated that the protocols used were reproducible. In this study, cow-to-cow variation contributed substantially to larger standard errors. Although a Latin square is an appropriate experimental design, treatment replications ( $\mathrm{n}=4$ per treatment) were obtained from different cows. The following factors may have contributed to the variation observed: limited number of cattle in the study, number of breeds [Holsteins $(\mathrm{n}=2)$ and crossbreeds $(n=2)]$, order of treatment received in reference to stage of lactation, and multiple processing steps for each treatment within each period (Murthy et al., 1972; Moreno-Rojas et al., 1993; Moreno-Rojas et al., 1994). Table 3 illustrates the variation in concentration of these minerals in processed milk by treatment, as well as individual cow-to-cow variation. A 2-way interaction of treatment $\times \operatorname{cow}(P<0.05)$ existed for $\mathrm{Ca}, \mathrm{Cu}$, and $\mathrm{Fe}$ (Figure 2).

The TBARS values of processed milk for the first and second week of analyses were averaged, because there were no significant differences with time $(P>$ 0.05; Table 4); mean values ranged from 1.0 to $1.9 \mathrm{mg}$ of MDA $/ \mathrm{kg}$ of milk. Processed milk in the direct addition study had lower starting MDA levels than the infused Fe processed milk, likely because of different handling methods (commercial vs. experimental). We observed no overall treatment effect $(P>0.05)$, although milk from 3 of the 4 cows showed a general increase with increasing $\mathrm{Fe}$ infusion concentration (data not shown). The linear regression of MDA levels in response to treatment concentration was not significant $\left(P=0.18 ; \mathrm{R}^{2}=0.03\right)$. However, when cow 4558 was omitted, the effects of treatment on MDA were significant $\left(P=0.004 ; \mathrm{R}^{2}=0.17\right)$, suggesting that cow variation may have affected the MDA levels in the processed milk. Spontaneous oxidation of milk, which can occur seemingly without reason and often in specific cows (Frankel, 1991; Nicholson and Charmley, 1993; Timmons et al., 2001), might be linked to changes in mineral composition and protein stability associated with water sources. Iron contamination of water may lead to spontaneous oxidation in the final milk product (Hegenauer et al., 1979b). However, with spontaneous oxidation, we would expect cow 4558 to consistently 


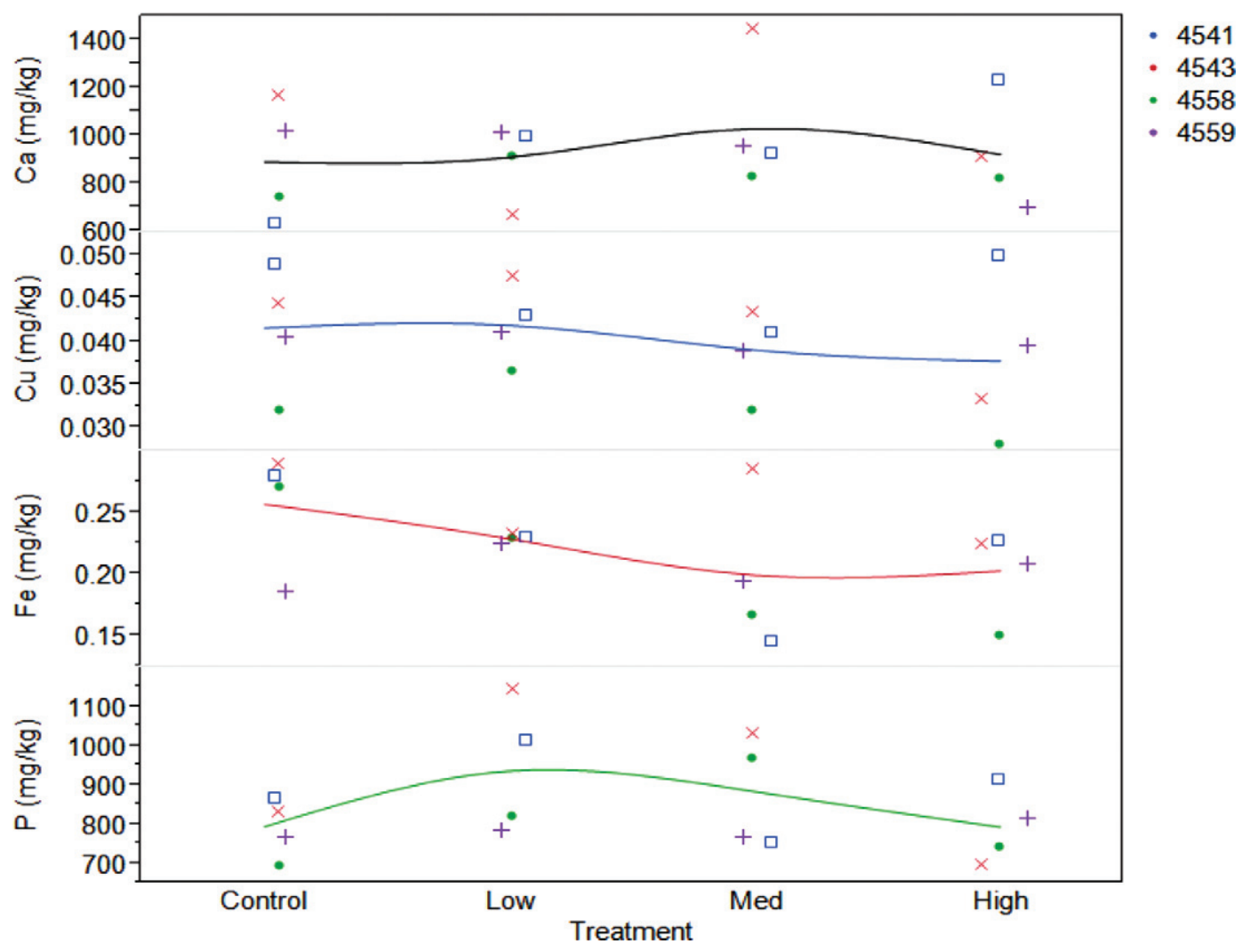

Figure 2. Mineral content ( $\mathrm{mg} / \mathrm{kg} ;$ mean; $\mathrm{n}=4 ; \mathrm{d} 1, \mathrm{~d} 8$ values as duplicates) as determined by inductively coupled plasma mass spectrometry on whole processed (pasteurized, homogenized) milk from cattle infused with iron to their abomasum. A 2-way interaction of treatment $\times$ cow $(P<0.05)$ existed for Ca, Cu, and Fe. Dietary iron water concentrations for the cattle were control $(0 \mathrm{mg} / \mathrm{kg}), \mathrm{low}(200 \mathrm{mg} / \mathrm{kg}), \mathrm{medium}$ $(500 \mathrm{mg} / \mathrm{kg})$, and high $(1,250 \mathrm{mg} / \mathrm{kg})$. Four 2-wk periods of milk collection are represented. Each shape (color) represents 1 of 4 cows. Milk was stored for $11 \mathrm{~d}\left(4^{\circ} \mathrm{C}\right.$; no light exposure). Color version available in the online PDF.

show more oxidized milk than other cows in the study. This inconsistency could be associated with order of $\mathrm{Fe}$ treatment or an effect of Fe treatment.

Differences in oxidative stability may be related to concentrations of antioxidants, including proteins, to- copherols, and vitamin $\mathrm{C}$, and activity level within the milk from each cow. Lactoferrin, a serum protein, binds both $\mathrm{Fe}^{2+}$ and $\mathrm{Fe}^{3+}$ ions and also has been observed to bind $\mathrm{Cu}^{2+}, \mathrm{Zn}^{2+}$, and $\mathrm{Mn}^{2+}$ ions (González-Chávez et al., 2009), contributing to control of oxidation. Trans-

Table 3. Mineral content ( $\mathrm{mg} / \mathrm{kg}$; mean $\pm \mathrm{SE}$ ), as determined by inductively coupled plasma mass spectrometry, on whole processed (pasteurized, homogenized) milk from cattle infused with iron to their abomasum ${ }^{1}$

\begin{tabular}{lcccc}
\hline Treatment & $\mathrm{Ca}(\mathrm{mg} / \mathrm{kg})$ & $\mathrm{Cu}(\mathrm{mg} / \mathrm{kg})$ & $\mathrm{Fe}(\mathrm{mg} / \mathrm{kg})$ & $\mathrm{P}(\mathrm{mg} / \mathrm{kg})$ \\
\hline Control $(0 \mathrm{mg} / \mathrm{kg}$ iron$)$ & $925 \pm 128$ & $0.042 \pm 0.003$ & $0.255 \pm 0.029$ & $794 \pm 43$ \\
Low $(200 \mathrm{mg} / \mathrm{kg}$ iron $)$ & $901 \pm 119$ & $0.042 \pm 0.003$ & $0.230 \pm 0.021$ & $943 \pm 103$ \\
Medium $(500 \mathrm{mg} / \mathrm{kg}$ iron $)$ & $1,041 \pm 160$ & $0.039 \pm 0.003$ & $0.198 \pm 0.034$ & $881 \pm 97$ \\
High $(1,250 \mathrm{mg} / \mathrm{kg}$ iron $)$ & $871 \pm 78$ & $0.036 \pm 0.004$ & $0.196 \pm 0.018$ & $771 \pm 56$ \\
Average $^{2}$ & $935 \pm 26$ & $0.040 \pm 0.001$ & $0.220 \pm 0.010$ & $847 \pm 27$ \\
USDA-reported values $^{3}$ & 113 & 0.110 & 0.300 & 910 \\
\hline
\end{tabular}

${ }^{1}$ Milk obtained from cows $[\mathrm{n}=4$; ( $\mathrm{d} 1, \mathrm{~d} 8)$ values as duplicates $]$ infused in the abomasum with ferrous lactate solution at 4 concentrations. Ferrous lactate solutions were made using ultrapure water and were provided for $4 \mathrm{~d}$ before milk collection. All four 2-wk periods of milk collection are represented. Milk was stored for a total of $11 \mathrm{~d}\left(4^{\circ} \mathrm{C}\right.$; no light exposure). No statistically significant differences $(P>0.05)$ were found among the different treatments using ANOVA.

${ }^{2}$ Day 1 and d 8 differences in mineral composition were not statistically significant $(P>0.05)$ using a TukeyKramer analysis.

${ }^{3}$ USDA (2013). 
Table 4. Malondialdehyde (MDA) concentration $(\mathrm{mg} / \mathrm{kg}$; mean $\pm \mathrm{SE})$, as indication of oxidation on whole processed (pasteurized, homogenized) milk from cattle infused in the abomasum with iron ${ }^{1}$

\begin{tabular}{lccc}
\hline Treatment & Day 1 of storage & Day 8 of storage & Overall $^{2}$ \\
\hline Control $(0 \mathrm{mg} / \mathrm{kg}$ iron $)$ & $0.975 \pm 0.285$ & $1.37 \pm 0.141$ & $1.17 \pm 0.22$ \\
Low $(200 \mathrm{mg} / \mathrm{kg}$ iron $)$ & $1.76 \pm 0.421$ & $1.32 \pm 0.138$ & $1.53 \pm 0.25$ \\
Medium $(500 \mathrm{mg} / \mathrm{kg}$ iron $)$ & $1.71 \pm 0.375$ & $1.18 \pm 0.137$ & $1.44 \pm 0.25$ \\
High $(1,250 \mathrm{mg} / \mathrm{kg}$ iron $)$ & $1.91 \pm 0.480$ & $1.45 \pm 0.336$ & $1.68 \pm 0.41$ \\
Average & $1.59 \pm 0.074$ & $1.33 \pm 0.020$ & $1.46 \pm 0.04$ \\
\hline
\end{tabular}

${ }^{1}$ Milk obtained from cows $(n=4)$ infused in the abomasum with ferrous lactate solution at 4 concentrations. Ferrous lactate solutions were made using ultrapure water and were provided for $4 \mathrm{~d}$ before milk collection. All four 2-wk periods of milk collection are represented. Each test was run in duplicate. Milk was stored for a total of $11 \mathrm{~d}\left(4^{\circ} \mathrm{C}\right.$; no light exposure). No statistically significant differences $(P>0.05)$ were found among the different treatments using ANOVA.

${ }^{2}$ Day 1 and d 8 differences in MDA $(\mathrm{mg} / \mathrm{kg})$ were not statistically significant $(P>0.05)$ using a Tukey-Kramer analysis.

ferrin and ovotransferrin also chelate iron (Madureira et al., 2007; González-Chávez et al., 2009).

Mean MDA concentrations of $1.61 \pm 0.238 \mathrm{mg} / \mathrm{kg}$ have been reported within $24 \mathrm{~h}$ of raw milk collection (Suriyasathaporn et al., 2006) and are comparable to the MDA concentrations observed in the processed milk in this study. No significant differences in MDA in processed milk were observed from the infusion of Fecontaining water into the abomasum, although variation in samples from individual cows was high. When Fe-contaminated water was directly added to milk in the direct $\mathrm{Fe}$ addition experiment, we observed an increase in oxidation, and the standard deviations were not as high as observed in the milk from cows infused with iron-containing water (Figure 1). Although the TBARS analysis is limited to the detection of MDA, it can be an indication that similar secondary oxidative products are also in the milk, such as other aldehydes (Moore and Roberts, 1998).

Guzun-Cojocaru et al. (2011) used the TBARS procedure to find values for MDA over a week-long period to show the time effect of $\mathrm{Fe}$ added to emulsions; they reported MDA levels to be higher in emulsions with $\mathrm{Fe}$ compared with the control with no Fe (Guzun-Cojocaru et al., 2011). The TBARS assay has been used to com- pare relative oxidation rates in comparison studies between different Fe fortification levels (Hegenauer et al., 1979a,b). In the current study, the test power was weak (0.14) for the analysis of treatment effect on MDA. No significant difference was found among MDA values in milk from the different cows, based on Tukey-Kramer analysis $(P>0.05)$. Each cow was represented in each of the 4 treatments. Processing conditions could easily affect oxidation rates because temperature and light exposure affect oxidative stability and consequently may be reflected in the MDA concentration of samples (Suriyasathaporn et al., 2006; Drake et al., 2007; Clark et al., 2009). Laboratory conditions were controlled as completely as possible in the current study.

Although analytical tests did not indicate any effects of abomasal infusion of ferrous lactate solutions on oxidative stability of the processed milk, triangle testing sensory discrimination methods showed that panelists could readily discern differences between each treatment sample when compared with the control $(P$ $<0.01$; data not shown). A minimum of 58 correct responses per test comparison (144 total responses per comparison for each week of analysis) were needed for the preset $\alpha=0.05$, and 62 correct responses were needed for an $\alpha=0.01$ to indicate a significant dif-

Table 5. Sensory triangle test (no. of correct responses ${ }^{1}$ ) for difference on whole $(3.2 \%)$ laboratory processed (vat pasteurized, homogenized) milk from cattle infused with iron to their abomasum

\begin{tabular}{l}
\hline \multicolumn{7}{c}{ Period $^{3}$} \\
\cline { 2 - 8 } Treatment
\end{tabular}


ference; the lowest number of correct responses was 66 (low iron treatment) on $\mathrm{d} 1$ and the medium and high treatments had 79 and 80 correct responses, respectively. After 1 wk of refrigerated storage (d 8; no light exposure), each comparison (control vs. treatment) had more than 80 correct responses, indicating a significant change in flavor in the treatment samples compared with the control. Triangle tests, commingled over the 4 test periods with 2 sessions per period $\left(\mathrm{n}=288\right.$; $\mathrm{p}_{\mathrm{d}}$ $=30 \%, \alpha=0.05, \beta=0.001)$, had a high degree of power (0.999) compared with each individual session (n $=36, \mathrm{p}_{\mathrm{d}}=30 \%, \alpha=0.05, \beta=0.3$ ), where the power was fair (0.7). The preset $\mathrm{p}_{\mathrm{d}}$ was $30 \%$ for the triangle test for difference but the actual $\mathrm{p}_{\mathrm{d}}$, based on the commingled pool of panelists, was 27,36 , and $39 \%$ for low, medium, and high treatments, respectively, suggesting that increasing concentration of infused iron into the abomasum had an effect on the sensory quality of the processed milk.

Discrimination tests do not identify the nature of the difference between control and treatment samples so it is not possible to describe the characteristics that caused the perceptible difference. Lipid oxidation can lead to the production of certain compounds that can be detected by humans; sensory perception is often used because it is more sensitive than analytical methods (Ogden, 1993). It is probable that differences detected between control and treatment milk products were related to very low concentrations of several different aldehydes and other flavor compounds associated with oxidation (Kristensen et al., 2004; Alvarez, 2009; Webster et al., 2009). However, because this study used 1 cow per treatment per period, we must acknowledge that it is possible that differences in milk flavors could be associated with cow-to-cow variation (Alvarez, 2009). Although the Latin square design allowed for each cow to be her own control in evaluating effects of the Fe treatments, within each period, the control milk used for the sensory testing was from 1 cow and was compared with the treatment milks from 3 different cows. The study did not include the assessment of milk in all cows when there was no abomasal infusion, which could have provided an indication whether any cow-to-cow variation in milk flavor was detectable. Although processing conditions were controlled as much as possible, each batch of milk (cow/treatment) was processed independently, and slight variations in temperature and time in the pasteurization vat may have occurred. This could cause slight differences in protein denaturation, leading to flavor variations, although this effect was likely minimal (Powell, 2001).

Sensory testing cannot be exclusively replaced by other analytical tests (Ogden, 1993; Drake, 2007). The human senses capture more than just one stimulus at a time, unlike many instrumental methods. However, it is possible for relationships to be established between instrumental and sensory tests (Drake, 2007). When comparing the treatments (low, medium, high) to the control milk, sufficient numbers of panelists were able to discern a difference between the samples. This is primarily an indication that the added Fe in the dietary water may have a sensory effect on the milk that is otherwise undetectable by the analytical method used (Jenness, 1974).

\section{CONCLUSIONS}

Quality of water for human consumption is carefully monitored but the water supply for dairy herds producing grade A milk does not have a USEPA-defined SMCL for Fe. Iron added directly to milk has been shown to increase the oxidation rates of milk. The mineral content of water used for bovine drinking water and in cleaning and sanitation in dairy production and processing operations should be considered as an important quality control factor for protecting milk quality. Until now, the effect of dietary Fe of bovine drinking water on milk quality was largely unstudied. It is likely that high levels $(>0.3 \mathrm{mg} / \mathrm{kg}$, USEPA SMCL) of Fe given to cattle in their drinking water does not accelerate oxidation rates of milk or alter mineral composition in a significant manner, but subtle differences may affect processing (e.g., cheese) and sensory characteristics of milk. High Fe contamination of bovine drinking water may affect some cows more than others, with a direct effect on the milk from one cow and a more subtle, but important, effect on the commingled milk supply. Awareness of the mineral concentration in water is important in protecting the quality of the final milk product. Both farmers and processors should be aware of the mineral content of water used for operations. These results may have national and international implications pertaining to water use, reuse, or recycling in dairy production and processing operations.

\section{ACKNOWLEDGMENTS}

This project was partially funded by the John Lee Pratt Foundation (Virginia Tech, Blacksburg). The authors acknowledge Xin Feng (Department of Dairy Science, Virginia Tech, Blacksburg) for her design and management of the pre-harvest study.

\section{REFERENCES}

Alvarez, V. B. 2009. Fluid milk and cream products. Chapter 5 in The Sensory Evaluation of Dairy Products. 2nd ed. S. Clark, M. Costello, M. Drake, and F. Bodyfelt, ed. Springer Science + Business Media, New York, NY.

Journal of Dairy Science Vol. 96 No. 12, 2013 
Anonymous. 2010. Stainless Steel in the Dairy Industry. International Stainless Steel Forum, Brussels, Belgium.

AOAC International. 2000. Official Methods of Analysis. Vol. 2. 17th ed. AOAC International, Gaithersburg, MD.

Ayotte, J. D., J. A. M. Gronberg, and L. E. Apodaca. 2011. Trace elements and radon in groundwater across the United States, 1992-2003. Scientific Investigations Report. US Geological Survey, Reston, VA.

Balintova, M., and A. Petrilakova. 2011. Study of pH influence on selective precipitation of heavy metals from acid mine drainage. Chem. Eng. Trans. 25:1-6.

Birghila, S., S. Dobrinas, G. Stanciu, and A. Soceanu. 2008. Determination of major and minor elements in milk through ICP-AES. Environ. Eng. Mgmt. J. 7:805-808.

Bury, N. R., D. Boyle, and C. A. Cooper. 2011. Iron. Pages 201-251 in Fish Physiology. Vol. 31, Part A. C. M. Wood, A. P. Farrell, and C. J. Brauner, ed. Springer Science + Business Media, New York, NY.

Cerbulis, J., and H. M. Farrell. 1976. Composition of the milks of dairy cattle. II. Ash, calcium, magnesium, and phosphorus. J. Dairy Sci. 59:589-593.

Chaplin, L. C. 1984. Studies on micellar calcium phosphate: Composition and apparent solubility product in milk over a wide $\mathrm{pH}$ range. J. Dairy Res. 51:251-257.

Chase, L. 2006. How much water do dairy farms use? In AgFocus NWNY Dairy, Livestock and Field Crops Team. Vol. 2012. Cornell University, Ithaca, NY.

Clark, S., M. Costello, M. A. Drake, and F. W. Bodyfelt. 2009. The Sensory Evaluation of Dairy Products. 2nd ed. Springer US, New York, NY.

Collignon, P. J. 2009. Water recycling-Forwards or backwards for public health? Med. J. Aust. 191:238-239.

Drake, M. A. 2007. Invited review: Sensory analysis of dairy foods. J. Dairy Sci. 90:4925-4937.

Drake, M. A., K. R. Cadwallader, and M. Whetstine. 2007. Establishing links between sensory and instrumental analyses of dairy flavors: Example Cheddar cheese. Pages 51-77 in Flavor of Dairy Products. Vol. 971. K. R. Cadwallader, M. A. Drake, and R. J. McGorrin, ed. American Chemical Society, Ann Arbor, MI

FDA (Food and Drug Administration). 2011. Grade "A" Pasteurized Milk Ordinance. US Department of Health and Human Services, Public Health Service, Food and Drug Administration, Washington, DC

Feng, X., K. F. Knowlton, A. D. Dietrich, and S. Duncan. 2013. Effect of abomasal ferrous lactate infusion on phosphorus absorption in lactating dairy cows. J. Dairy Sci. 96:4586-4591. http://dx.doi. org/10.3168/jds.2013-6602.

Frankel, E. N. 1991. Recent advances in lipid oxidation. J. Sci. Food Agric. 54:495-511.

Gaucheron, F. 2000. Iron fortification in dairy industry. Trends Food Sci. Technol. 11:403-409.

Gaucheron, F., Y. Le Graet, K. Raulot, and M. Piot. 1996. Physicochemical characterization of iron-supplemented skim milk. Int. Dairy J. 7:141-148.

Goff, H. D., and A. R. Hill. 1993. Chemistry and physics. Pages 1-30 in Dairy Science and Technology Handbook. Vol. 1. Y. H. Hui, ed. John Wiley \& Sons, New York, NY.

González-Chávez, S. A., S. Arévala-Gallegos, and Q. Rascón-Cruz. 2009. Lactoferrin: Structure, function and applications. Int. J. Antimicrob. Agents 33:301.e1-301.e8.

Guzun-Cojocaru, T., C. Koev, M. Yordanov, T. Karbowiak, E. Cases, and P. Cayot. 2011. Oxidative stability of oil-in-water emulsions containing iron chelates: Transfer of iron from chelates to milk proteins at interface. Food Chem. 125:326-333.

Haraguchi, H., Y. Zhu, R. Hattori, A. Itoh, and T. Umemura. 2004. Multielement analysis of commercial mineral waters by chelating resin preconcentration and ICP-MS. Biomed. Res. Trace Elem. $15: 355-357$.

Havemose, M. S., M. R. Weisbjerg, W. L. P. Bredie, H. D. Poulsen, and J. H. Nielsen. 2006. Oxidative stability of milk influenced by fatty acids, antioxidants, and copper derived from feed. J. Dairy Sci. 89:1970-1980

Hegenauer, J., D. Ludwig, and P. Saltman. 1979a. Effects of supplemental iron and copper on lipid oxidation in milk. 2. Comparison of metal complexes in heated and pasteurized milk. J. Agric. Food Chem. 27:868-871.

Hegenauer, J., P. Saltman, D. Ludwig, L. Ripley, and P. Bajo. 1979b. Effects of supplemental iron and copper on lipid oxidation in milk 1. Comparison of metal complexes in emulsified and homogenized milk. J. Agric. Food Chem. 27:860-867.

Hunt, C. D., and S. L. Meacham. 2001. Aluminum, boron, calcium, copper, iron, magnesium, manganese, molybdenum, phosphorus, potassium, sodium, and zinc: Concentrations in common Western foods and estimated daily intakes by infants; toddlers; and male and female adolescents, adults, and seniors in the United States. J. Am. Diet. Assoc. 101:1058-1060.

Hunt, C. D., and F. H. Nielsen. 2009. Nutritional aspects of minerals in bovine and human milks. Pages 391-456 in Advanced Dairy Chemistry. Vol. 3. 3rd ed. P. McSweeney and P. F. Fox, ed. Springer Science + Business Media, New York, NY.

Hutkins, R. W. 2006. Microbiology and Technology of Fermented Foods. IFT Press Blackwell Publ., Ames, IA.

Jenness, R. 1974. Biosynthesis and composition of milk. J. Invest. Dermatol. 63:109-118.

Jensen, R. G. 1995. Handbook of Milk Composition. Academic Press, San Diego, CA.

Johnson, D. S., S. E. Duncan, W. N. Eigel, and S. F. O'Keefe. 2013 Light-protective packaging effectiveness to enhance sensory and nutrient stability of extended shelf-life milk and omega-3 enriched milk. J. Dairy Sci. 96(E-Suppl. 1):84. (Abstr.)

Kristensen, D., R. V. Hedegaard, J. H. Nielsen, and L. H. Skibsted. 2004. Oxidative stability of buttermilk as influenced by the fatty acid composition of cows' milk manipulated by diet. J. Dairy Res. 71:46-50.

Laird, D. T., S. A. Gambrel-Lenarz, F. M. Scher, T. E. Graham, R. Reddy, and L. J. Maturin. 2004. Microbiological count methods. Pages 153-186 in Standard Methods for the Examination of Dairy Products. 17 ed. H. M. Wehr and J. F. Frank, ed. American Public Health Association, Washington, DC.

Madureira, A. R., C. I. Pereira, A. M. P. Gomes, M. E. Pintado, and F. X. Malcata. 2007. Bovine whey proteins-Overview on their main biological properties. Food Res. Int. 40:1197-1211.

Mann, G., K. Phetxumphou, E. Gibson, C. Martel, S. Duncan, A. Dietrich, R. James, and K. Knowlton. 2013. Can iron in water affect milk production? Virginia Dairyman 9:26-27.

Matak, K. E., S. S. Sumner, S. E. Duncan, E. Hovingh, R. W. Worobo, C. R. Hackney, and M. D. Pierson. 2007. Effects of ultraviolet irradiation on chemical and sensory properties of goat milk. J. Dairy Sci. 90:3178-3186.

McKie, A. T., D. Barrow, G. O. Latunde-Dada, A. Rolfs, G. Sager, E. Mudaly, M. Mudaly, C. Richardson, D. Barlow, A. Bomford, T. J. Peters, K. B. Raja, S. Shirali, M. A. Hediger, F. Farzaneh, and R. J. Simpson. 2001. An iron-regulated ferric reductase associated with the absorption of dietary iron. Science 291:1755-1759.

McNeill, L. S. 2006. Water quality factors influencing iron and lead corrosion in drinking water. PhD Diss. Virginia Polytechnic Institute and State University, Blacksburg.

Meilgaard, M., G. V. Civille, and B. T. Carr. 2007. Sensory Evaluation Techniques. 4th ed. Taylor \& Francis, Boca Raton, FL.

Moore, K., and L. J. Roberts. 1998. Measurement of lipid peroxidation. Free Radic. Res. 28:659-671.

Moore, R. L., S. E. Duncan, A. S. Rasor, W. N. Eigel, and S. F. O'Keefe. 2012. Oxidative stability of an extended shelf-life dairybased beverage system designed to contribute to heart health. J. Dairy Sci. 95:6242-6251.

Moreno-Rojas, R., M. A. Amaro-Lopez, and G. Zurera-Cosano. 1993. Micronutrients in natural cow, ewe and goat milk. Int. J. Food Sci. Nutr. 44:37-46.

Moreno-Rojas, R., G. Zurera-Cosano, and M. A. Amaro-Lopez. 1994. Concentration and seasonal variation of calcium, magnesium, so- 
dium and potassium in raw cow, ewe and goat milk. Int. J. Food Sci. Nutr. 45:99-105.

Murthy, G. K., U. S. Rhea, and J. T. Peeler. 1972. Copper, iron, manganese, strontium, and zinc content of market milk. J. Dairy Sci. 55:1666-1674.

Nicholson, J. W. G., and E. Charmley. 1993. Injectable alpha-tocopherol for control of oxidized flavor in milk from dairy cows. Can. J. Anim. Sci. 73:381-392.

Ogden, L. V. 1993. Sensory evaluation of dairy products. Pages 157175 in Dairy Science and Technology Handbook. Vol. 1. Y. H. Hui, ed. John Wiley \& Sons, New York, NY.

Powell, J. 2001. The sensory and analytical analyses of nonfat milk formulations: Stability to light oxidation and pasteurization. MS Diss. Virginia Polytechnic Institute and State University, Blacksburg.

Raouche, S., S. Naille, M. Dobenesque, A. Bot, J.-C. Jumas, J.-L. Cuq, and S. Marchesseau. 2009. Iron fortification of skim milk: Minerals and ${ }^{57} \mathrm{Fe}$ Mössbauer study. Int. Dairy J. 19:56-63.

Rice, E. W., R. B. Baird, A. D. Eaton, and L. S. Clesceri. 2012. Standard Methods for the Examination of Water and Wastewater. 22nd ed. American Public Health Association, Washington, DC.

Rodríguez Rodríguez, E. M., M. Sanz Alaejos, and C. Díaz Romero. 1999. Chemometric studies of several minerals in milks. J. Agric. Food Chem. 47:1520-1524.

Rosegrant, M. W., and X. M. Cai. 2002. Global water demand and supply projections: Part 2. Results and prospects to 2025. Water Int. 27:170-182.

Satué-Gracia, M. T., E. N. Frankel, N. Rangavajhyala, and J. B. German. 2000. Lactoferrin in infant formulas: Effect on oxidation. J. Agric. Food Chem. 48:4984-4990.

Sikiric, M., N. Brajenovic, I. Pavlovic, J. L. Havranek, and N. Plavljanic. 2003. Determination of metals in cow's milk by flame atomic absorption spectrophotometry. Czech J. Anim. Sci. 48:481-486.

Spanier, A. M., and R. D. Traylor. 1991. A rapid, direct chemical assay for the quantitative determination of thiobarbituric acid reactive substances in raw, cooked, and cooked/stored muscle foods. J. Muscle Foods 2:165-176.
Suddendorf, R. F., and K. K. Cook. 1984. Inductively coupled plasma emission spectroscopic determination of nine elements in infant formula: Collaborative study. J. Assoc. Off. Anal. Chem. 67:985992.

Sugiarto, M., A. Ye, M. W. Taylor, and H. Singh. 2010. Milk proteiniron complexes: Inhibition of lipid oxidation in an emulsion. Dairy Sci. Technol. 90:87-98.

Suriyasathaporn, W., U. Vinitketkumnuen, T. Chewonarin, S. Boonyayatra, K. Kreausukon, and Y. H. Schukken. 2006. Higher somatic cell counts resulted in higher malondialdehyde concentrations in raw cows' milk. Int. Dairy J. 16:1088-1091.

Timmons, J. S., W. P. Weiss, D. L. Palmquist, and W. J. Harper. 2001. Relationships among dietary roasted soybeans, milk components and spontaneous oxidized flavor of milk. J. Dairy Sci. 84:2440-2449.

Underwood, E. J. 1971. Trace Elements in Human and Animal Nutrition. No. XIV. Academic Press, New York, NY.

USEPA (US Environmental Protection Agency). 2011. 40CFR Part 141-142: National Primary Drinking Water Regulations. Accessed Sep. 13, 2013. http://www.gpo.gov/fdsys/pkg/CFR-2011-title40-vol23/pdf/CFR-2011-title40-vol23-part141.pdf and http:// www.gpo.gov/fdsys/pkg/CFR-2011-title40-vol23/pdf/CFR-2011title40-vol23-part142.pdf.

USDA (US Department of Agriculture). 2013. Nutrient Database for Standard Reference. Accessed Sep. 30, 2013. ndb.nal.usda.gov.

Upreti, P., and L. E. Metzger. 2007. Influence of calcium and phosphorus, lactose, and salt-to-moisture ratio on cheddar cheese quality: $\mathrm{pH}$ changes during ripening. J. Dairy Sci. 90:1-12.

van Aardt, M., S. E. Duncan, J. E. Marcy, T. E. Long, S. F. O'Keefe, and S. R. Nielsen-Sims. 2005. Effect of antioxidant ( $\alpha$-tocopherol and ascorbic acid) fortification on light-induced flavor of milk. J. Dairy Sci. 88:872-880.

Webster, J. B., S. E. Duncan, J. E. Marcy, and S. F. O'Keefe. 2009. Controlling light oxidation flavor in milk by blocking riboflavin excitation wavelengths by interference. J. Food Sci. 74:S390-S398.

White, C. H., and M. Bulthaus. 1982. Light activated flavor in milk. J. Dairy Sci. 65:489-494. 